\title{
Evaluation of Different Growth Media for Clavibacter michiganensis subsp michiganensis and Formation of Biofilm like Structures
}

\author{
Ruchi Tripathi*, Rashmi Tiwari and K. Vishunavat \\ Department of Plant Pathology, College of Agriculture, G B Pant University of Ag and \\ Technology, India \\ *Corresponding author
}

\begin{tabular}{|l|}
\hline K e y w o r d s \\
$\begin{array}{l}\text { Tomatoes, Cmm, Growth } \\
\text { medium, Biofilm like } \\
\text { structures formation, } \\
\text { Selectivity }\end{array}$ \\
\hline Article Info \\
\hline $\begin{array}{l}\text { Accepted: } \\
\text { 04 April } 2018 \\
\text { Available Online: } \\
\text { 10 May } 2018\end{array}$ \\
\hline
\end{tabular}

A B S T R A C T
The studies to work out the most suitable medium for the growth of Clavibacter michiganensis subsp michiganensis was carried out using nonselective (NA, NGY, YPGA, YDCA and SPY) and semi-selective media (SCM, $\mathrm{D}_{2} \mathrm{ANX}$ ). Besides the systemic nature of the pathogen was assessed through formation of biofilm like structures in xylem sap (XS), minimal medium, LB broth and in distills water under in vitro condition. Amongst the tested nonselective medium NGY was observed to be the most suitable medium for growth with a growth area ranging from $213-232 \mathrm{~mm}^{2}\left(4^{\text {th }} \mathrm{DAP}\right)$ and $1389-1412 \mathrm{~mm}^{2}\left(10^{\text {th }}\right.$ DAP). Amongst the semi- selective media, $\mathrm{D}_{2} \mathrm{ANX}$ was observed to be the most effectual for the bacterial growth with a growth area ranging from $26-58 \mathrm{~mm}^{2}$ and $32-61 \mathrm{~mm}^{2}\left(10^{\text {th }}\right.$ DAP). Although, NGY medium was found to be the most suitable for the growth of the bacterium $\mathrm{Cmm}$ but at the same time it preferred the growth of bacteria other than $\mathrm{Cmm}$ whereas on $\mathrm{D}_{2} \mathrm{ANX}$ and SCM a slow growth of $\mathrm{Cmm}$ was observed yet these media did not support the growth of bacteria other than $\mathrm{Cmm}$. For the formation of biofilm like structure, the maximum aggregates formation of the pathogen was observed in xylem sap by five $\mathrm{Cmm}$ isolates with and OD value ranging between of 0.546- 0.162 , the least being in case of $\mathrm{Cmm} 1$ isolate.

\section{Introduction}

Clavibacter michiganensis subsp. michiganensis (Smith) Davis the causal agent of bacterial wilt and canker of tomato is a devastating disease of tomato both in the field and in the protected cultivation. The disease may lead to heavy economic losses, and very stringent cleanliness measures are required to be taken once the disease is observed (Strider, 1969). The pathogen has been under strict international quarantine and been categorized as an A2 quarantine organism by the European
Plant Protection Organization (OEPP/EPPO, 2005; Council Directive 2000/29/EC). The primary cause for the spread of bacterium into newer areas are infested seeds and transplants from the nurseries (Chang et al., 1991; Strider, 1969; Werner et al., 2002), however the soil transmission of the pathogen is of not much importance (Ftayeh, 2004; Ftayeh et al., 2004; Strider, 1969). The pathogen shows an array of symptoms in the tomato plant. A wide range of symptoms, depending upon the plant stages, time of infection, intercultural operations, location of production (glasshouse 
or field), and cultivar are produced on the plants. The disease affects all the plant part showing marginal necrosis in the leaves and canker on stem and fruits followed by wilting of the entire plant leading to the plant death (EPPO Bulletin, 2016). The recurrent factors, involved in the systemic growth of vascular pathogens are the formation of extensive bacterial aggregates and biofilm like structures attached to xylem surfaces (Danhorn and Fuqua, 2007).

The detection of the pathogen is the most important step in the disease diagnosis and for that reason the semiselective media can be considered as one of the cheap, convenient and most valuable diagnostic measures in the phytobacteriology (Roy and Sasser, 1990).

In the present study two semiselective and five nonselective media were evaluated for the growth of bacterium isolated from different tomato growing regions of Himachal Pradesh and Uttarakhand (Table 1) and the formation of biofilm like structures was assessed to elucidates the systemic vascular movement of C. michiganensis subsp. michiganensis.

\section{Materials and Methods}

\section{Isolation of Pathogen}

The bacterium was isolated from different infected plant parts (seeds, seedlings, stem, leaves and fruits) following the method by Janse (2005). The infected tissues were surface disinfected by alcohol (70\%) and were then placed in a petriplate having sterilized water. Infected plant tissues were gently crushed for $30 \mathrm{~min}$. in sterilized water to release the bacterial cells into the water. On the sterilized culture plates with Nutrient Agar Glucose Yeast medium (NGY) medium, a $100 \mu l$ of this suspension was then poured. On the other hand, the seeds collected from infected fruits were also placed on the sterilized culture plates with NGY medium @ 25 seed /plate and were kept in the growth chamber at $28 \pm 1^{\circ} \mathrm{C}$. After an incubation period of $72 \mathrm{~h}$, the culture plates were examined for the recovery of the bacterium from the infected plant parts and seeds.

\section{Evaluation of the selectivity and growth area of $\mathrm{Cmm}$ in different medium}

For the assessment of selectivity and growth area of $\mathrm{Cmm}$ on nonselective medium (NA, NGY SPY, YPGA and YDCA, (EPPO Bulletin, 2016), and semi-selective media SCM (Fatmi and Schaad, 1988), $\mathrm{D}_{2} \mathrm{ANX}$ medium (Chun, 1982), the ten isolated strains were placed on the respective sterilized media in culture plates. The bacterial cell suspension was made in $0.01 \mathrm{M}$ phosphate buffer saline (PBS) (pH: 7.0), the inoculums concentration in the suspension was adjusted spectrophotometerically to an OD value of 0.06 at $660 \mathrm{~nm}$ that corresponds to $10^{8} \mathrm{cfu}$ $\mathrm{ml}^{-1}$, and later diluted to $10^{4} \mathrm{cfu} \mathrm{ml}^{-1}$. Lastly, $100 \mu \mathrm{l}$ of $10^{4} \mathrm{cfu} \mathrm{ml}^{-1}$ bacterial cell suspension from each strain was streaked on the surface of the growth medium by a "L" shaped glass spatula. The experiment was conducted using three replications. The culture plates were kept in incubator at $28 \pm 1^{\circ} \mathrm{C}$ and observations were recorded in the form of growth area of $\mathrm{Cmm}$ $4_{\text {th }}$ and $10^{\text {th }}$ day after plating using the following formula A Area of growth in the medium $=$ cfu count $\mathrm{x}$ area of colony $\left.\left(\pi r^{2}\right)\right\}$ (Ftayeh et al., 2011).

\section{Evaluation of the colony characteristics of the $\mathrm{Cmm}$ isolates}

The ten different bacterial isolates from different locations of Himachal Pradesh and Uttarakhand (Table 1) were cultured on growth medium exhibiting the maximum bacterial growth. The plates were kept at incubator at $28 \pm 1^{\circ} \mathrm{C}$ and observations were recorded at $72 \mathrm{~h}$ of plating. 


\section{Biofilm like structure formation by $\mathrm{Cmm}$ isolates on different media}

\section{Crystal violet assay for bacterial attachment}

The assay for bacterial attachment was carried out following the procedure described by Davey and O'Toole (2000). The four most virulent isolates of $\mathrm{Cmm}$ viz., $\mathrm{Cmm} \mathrm{1,} \mathrm{5,} 6$ and 10 were grown on Luria Bertani broth medium at $28 \pm 1^{\circ} \mathrm{C}$ for $49 \mathrm{~h}$, separately.

These bacterial cultures were diluted at 1:1000 dilutions and once again transferred on to the same Luria Bertani broth medium to attain an $\mathrm{OD}_{595}=0.5$. The bacterial suspension, thus obtained, was centrifuged and the pellets were washed just the once and resuspended in $3 \mathrm{ml}$ of sterile water.

Thereafter, for each isolate, a 24-welled micro titrate plate was filled with four different media \{(Xylem Sap (XS), Minimal medium (M9), Luria Bertani broth medium (LB) and distilledwater (DW)\}@150 $\mu 1$ in each well having a replication of 3 well /medium. Thereafter, the bacterial suspension of $50 \mu 1$ was added to each well of the plate having different media. The plates were incubated for $72 \mathrm{~h}$ at $28^{\circ} \pm 1^{\circ} \mathrm{C}$ without agitation. After incubation period, the plates were gently removed and the medium in each well was pipette out and the wells were washed twice with $150 \mu \mathrm{l}$ of sterile water. For fixation of the bacterial film, the plates were kept in the water bath at $60^{\circ} \pm 1^{\circ} \mathrm{C}$ for $20 \mathrm{~min}$. and further stained with $0.1 \%$ crystal violet solution for $1 \mathrm{~h}$ at room temperature. The plates were subsequently washed gently, three times with $150 \mu \mathrm{l}$ of sterile water and air dried for $1 \mathrm{~h}$ for visual qualitative analysis. For quantitative analysis, crystal violet in each well was solubilized by adding $100 \mu \mathrm{l}$ of $95 \%$ ethanol and absorption of the solution was measured at $595 \mathrm{~nm}$ using a microtiter plate reader.

\section{Results and Discussion}

\section{Symptomatology}

The disease appears as cankerous lesion on the stem which increases in size chronically (A). Infection on the stem often also girdles the stem and may cause premature plant death. Infected stem when splitted longitudinally, brown discoloration of the internal tissues is observed (B). Unilateral wilting of infected leaves appears starting from the tip of the leaf most part and follows downside (C). Marginal necrosis in leaves is also observed accompanied with downward turning of the leaves as the infection progresses.

\section{Evaluation of selectivity and growth areas on different media}

Ten different strains isolated from different locations (Table 1), were subjected to study for the selectivity and growth on the different media. Faster growth of the bacterium was obtained in the non- selective media than semi-selective medium. Relatively faster growth was recorded on NGY, with in the non-selective media. In semi-selective media viz., $\mathrm{D}_{2} \mathrm{ANX}$ and SCM, the faster growth of the bacterium was observed $\mathrm{D}_{2} \mathrm{ANX}$ and only, the beginning of the growth was observed in SCM medium at $4^{\text {th }}$ day of plating (Fig. 1). Significant difference in growth areas was also observed in NGY medium as compared with other media. In case of semi-selective media, the maximum growth area was recorded on $\mathrm{D}_{2} \mathrm{ANX}$, in comparison with SCM medium while in non-selective media, the maximum growth area was recorded on NGY in comparison with other non-selective media used after ten days of plating (Fig. 2). However, the nonselective media were preferred by the bacterium for growth but for detection of the bacterium, semi-selective medium was more reliable as it did not allow the growth of bacteria other than $\mathrm{Cmm}$. 
Generally, on the nonselective media, the maximum bacterial growth was recorded within the first four days, whereas in semiselective medium the bacterial growth was slower than in non-selective media. In $\mathrm{D}_{2} \mathrm{ANX}$ medium, the growth in different bacterial strains started from $2^{\text {nd }}-6^{\text {th }}$ day of incubation may also be due to the variable growth potential of different bacterial strains. On semi-selective SCM medium, the bacterial strains exhibited slowest growth (starting from fourth day after plating) and in $\mathrm{Cmm} 1$ and $\mathrm{Cmm} 8$ isolates it was poorest.

The studies carried out by Hadas et al., (2005), also found that one of the Cmm-strains isolated by them did not grow on $\mathrm{D}_{2} \mathrm{ANX}$ medium and while others grew very slowly indicating the low growth rate of the $\mathrm{Cmm}$ on these media. Roy and Sasser (1990) also mentioned that direct isolation and plating onto semi-selective media remain the most widely used detection methods for specific bacterial pathogens as the semi-selective media are based on knowledge of the nutritional requirements and physiological tolerances of the target bacterium. The colony characteristics of the bacterial isolates in different medium are shown on Plate 2.

\section{Colony characteristics of $\mathrm{Cmm}$ in different media}

To study the effect of different media on growth pattern of $C$. michiganensis subsp michiganensis, an isolate 10 was used for the study. The bacterial colonies varied in color, shape and size when grown on different media. On NGY medium, colonies were found light yellow, creamish and orange, round and semi-fluidal wherein on SCM medium, the colonies appeared translucent green-grey, mucoid, with a variable grey to black centre. The colony characters of $\mathrm{Cmm}$ isolate as observed on SCM were in accordance with of the earlier workers Fatmi and Schaad (1988); and Umesha (2006) Further, on YPGA medium, the colonies appeared to be light yellow, flat and semi-fluidal, round or irregular becoming deeper yellow, opaque and glistening with the increase in the incubation period. On YDCA medium, the bacterial colonies were yellow, mucoid but often orange in colour which is in support with the observations made in the EPPO Bulletin (2016). On the D2ANX medium, the colonies were yellow, concave and become glistening with the time. Similar $\mathrm{Cmm}$ colonies growth pattern was observed by Chun (1982).

Fig.1 Growth areas in $\mathrm{mm}^{2}$ of 10 strains (as the mean of three replicates for each strain) on on different media (without addition of antibiotics) at the 4th day after plating following incubation at $28^{\circ} \mathrm{C}$. Growth area $=$ number of CFU $\times \pi r^{2}$ (r: average radius of colonies in $\left.\mathrm{mm}\right)$. Bars represent standard error

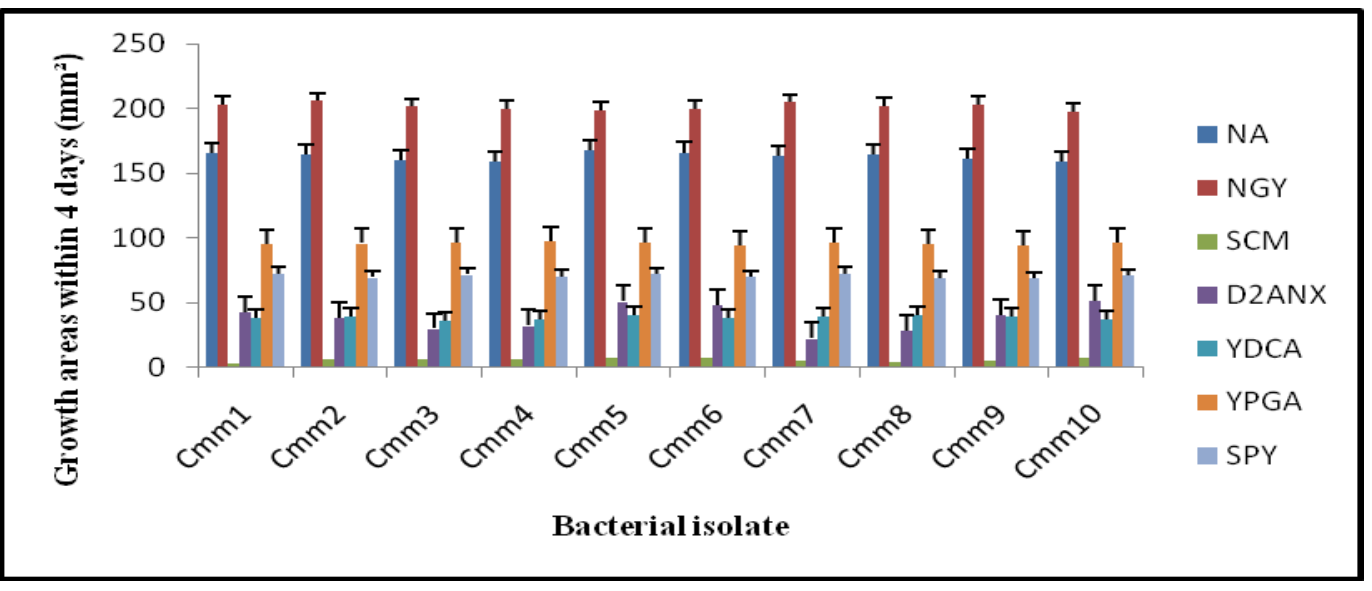


Fig.2 Growth areas in $\mathrm{mm}^{2}$ of 10 strains (as the mean of three replicates for each strain) on different media (without addition of antibiotics) at the 10th day after plating following incubation at $28^{\circ} \mathrm{C}$. Growth area $=$ number of CFU $\times \pi \mathrm{r}^{2}$ (r: average radius of colonies in $\mathrm{mm})$.Bars represent standard error

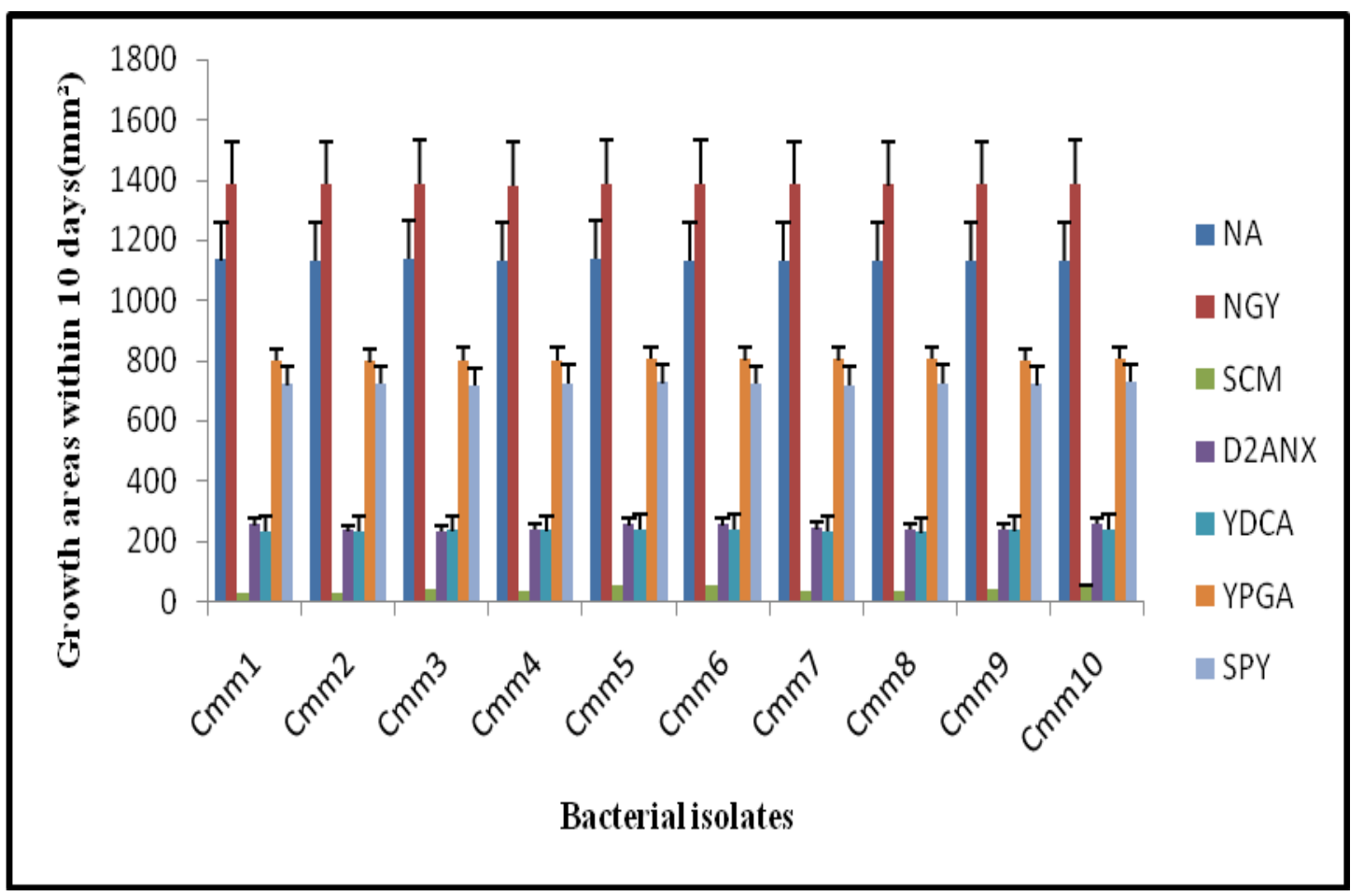

Fig.3 Quantitative estimation of biofilm formation by the bacterial isolates $\operatorname{Cmm}(1,5,6$, and 10) in different medium. Bars represent standard error $(\mathrm{p} \leq 0.05)$

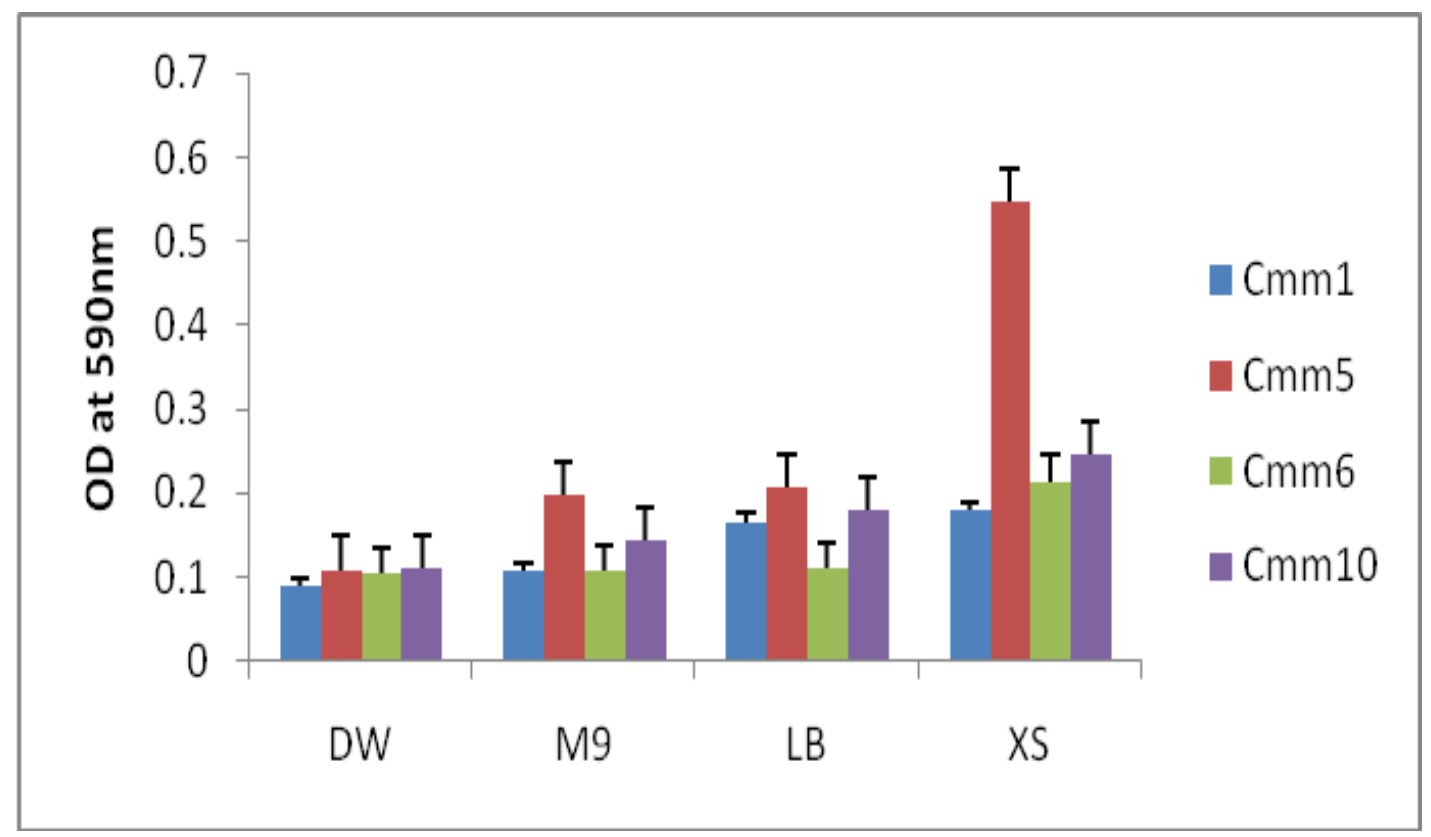




\section{Plate.1 Symptoms of Clavibacter michiganensis subsp. michiganensis}

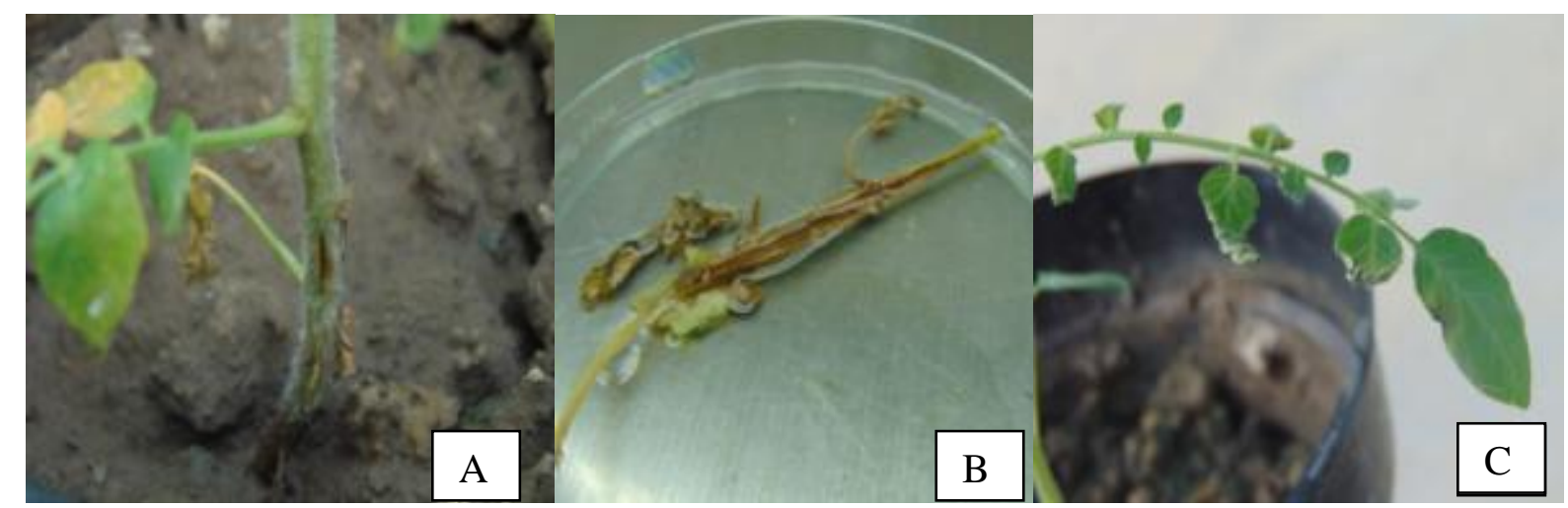

A. Stem canker

B. Discoloration or mealy appearance in the inner part of the stem

C. Unilateral wilting

Plate.2 Growth of bacterium isolate Cmm10 in different medium A SCM, B. D2ANX, C. NGY, D. YDCA, E. YPGA, F. SPY, G. NA
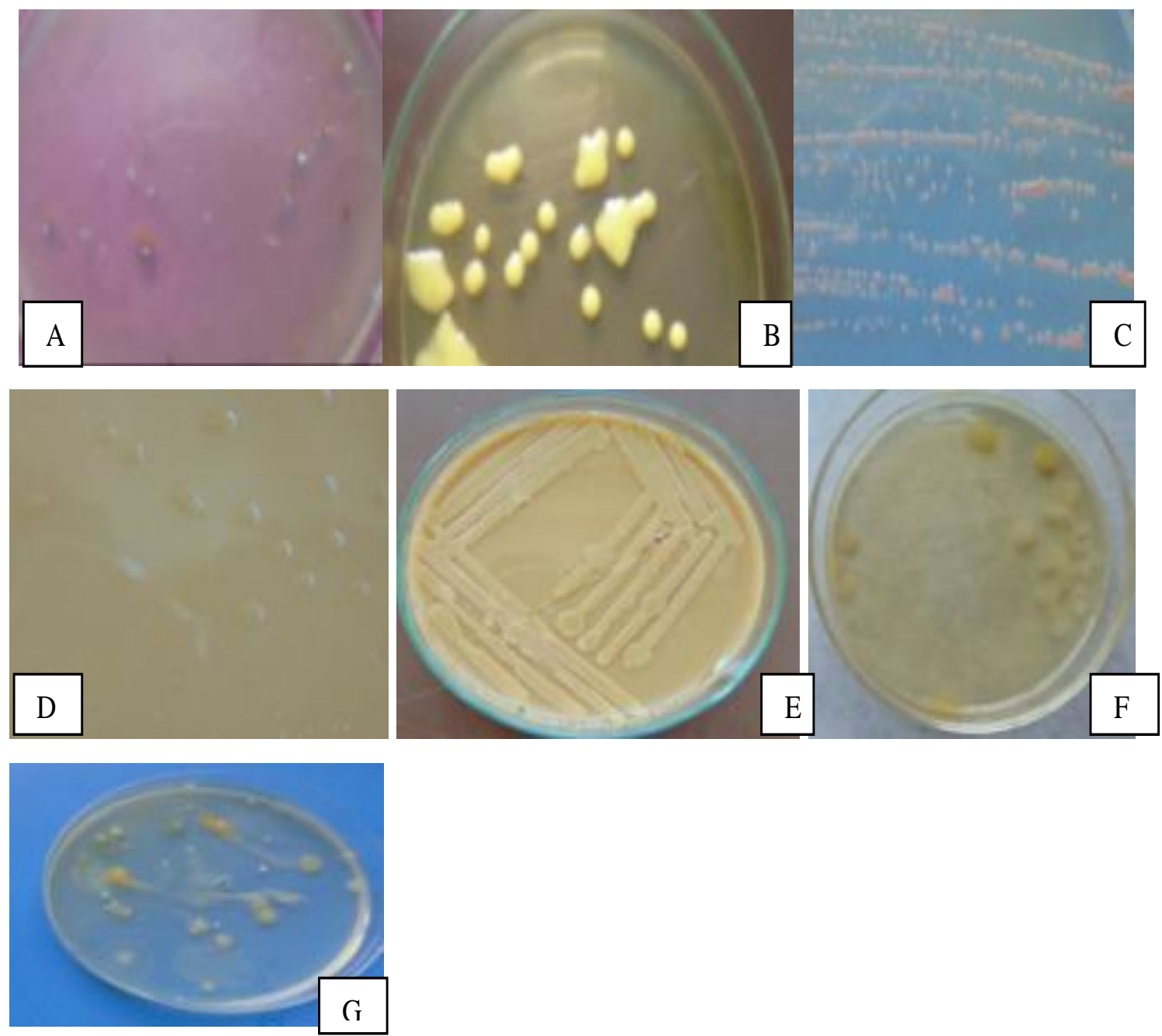
Plate.3 Cultural variability of different isolates $(\mathrm{Cmm} 1-\mathrm{Cmm} 10)$ of the bacterium
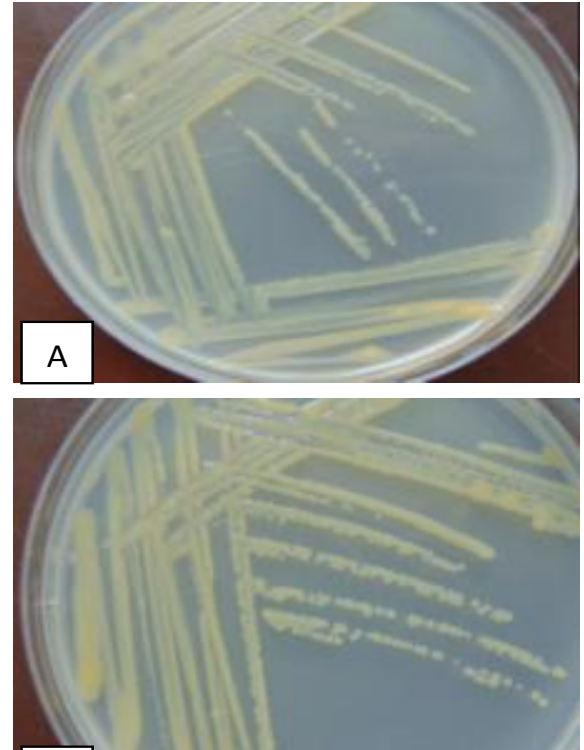

C

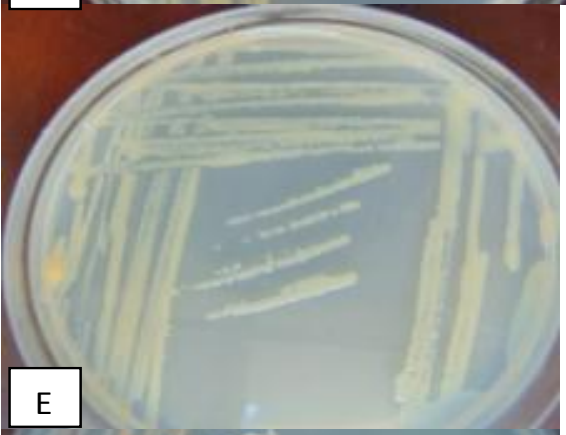

$\mathrm{E}$

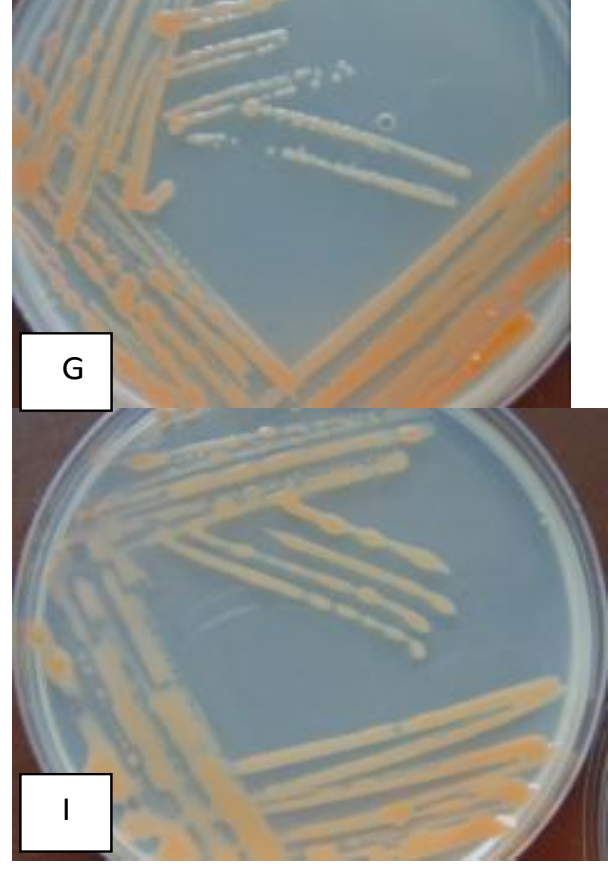

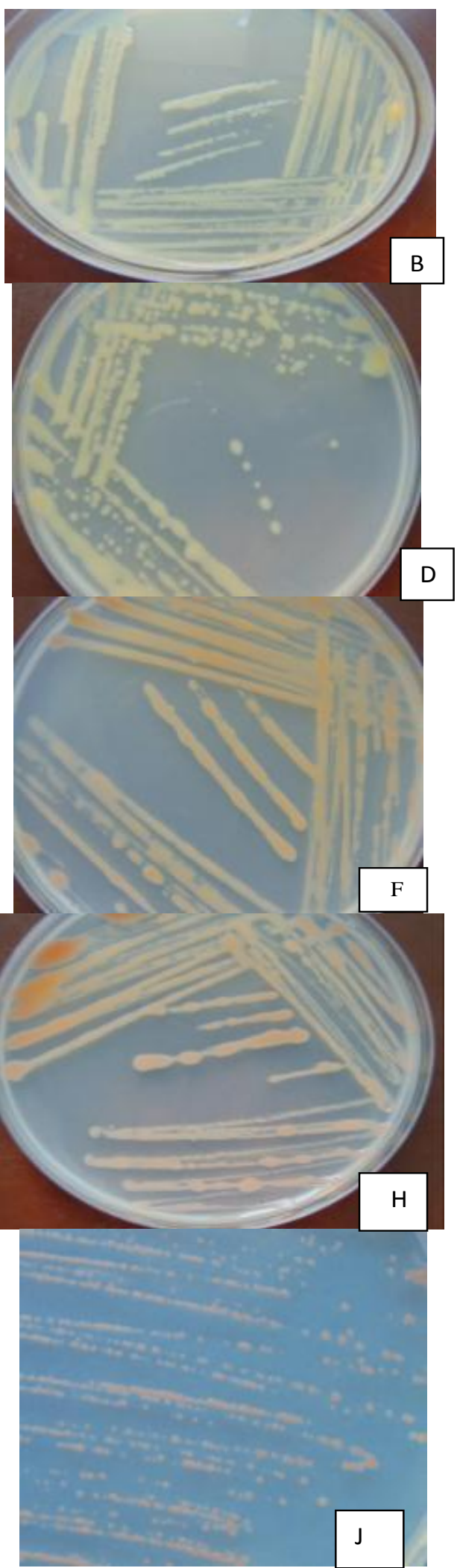


Plate.4 Biofilm formation by the bacterial isolates in different growth medium in the series of Cmm 10, Cmm 6, Cmm 5 and $\mathrm{Cmm} 1$

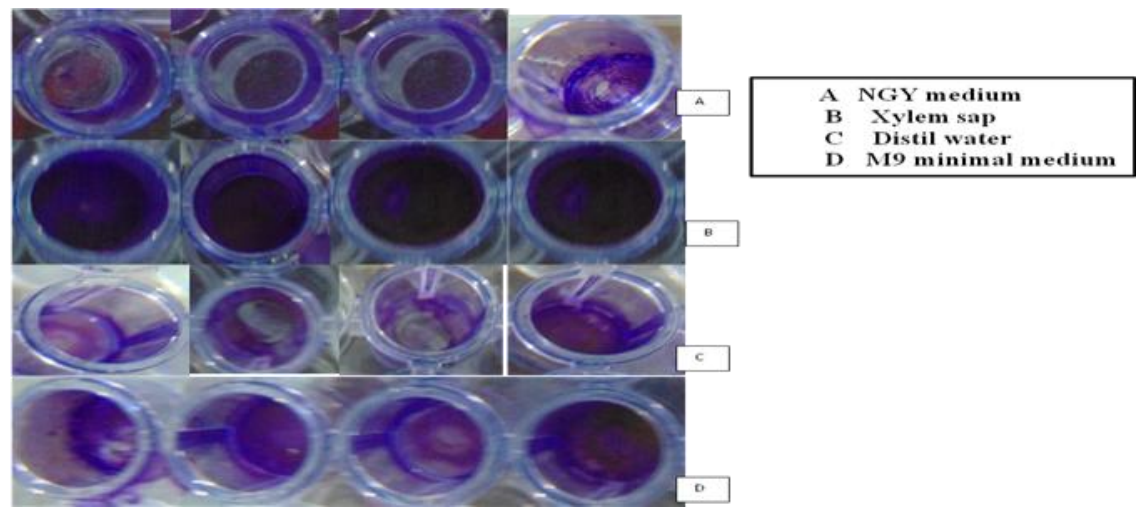

Table.1 Bacterial isolates from different location of HP and Uttarakhand

\begin{tabular}{|c|}
\hline S. No. \\
\hline 1 \\
\hline 2 \\
\hline 3 \\
\hline 4 \\
\hline 5 \\
\hline 6 \\
\hline 7 \\
\hline 8 \\
\hline 9 \\
\hline 10 \\
\hline
\end{tabular}

P.

\begin{tabular}{|c|}
\hline Isolate \\
\hline Nauni \\
\hline Khaltu \\
\hline Kalaghat \\
\hline Kotla Panjola \\
\hline Gaulapar \\
\hline Garganoo \\
\hline Narag \\
\hline Kyar \\
\hline Nainatikkar \\
\hline Deothal \\
\hline
\end{tabular}

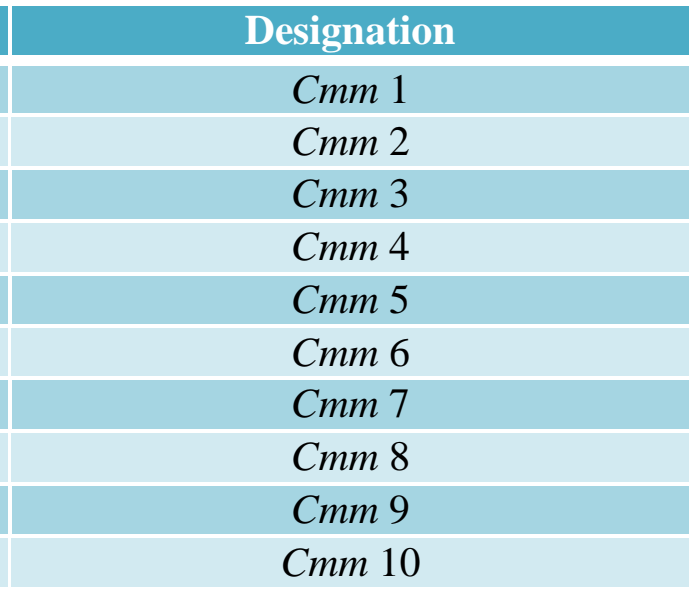

Table.2 Colony characteristics of different isolates of bacterial canker pathogen on nutrient agar glucose yeast medium

\begin{tabular}{|c|c|c|c|c|}
\hline \multirow[t]{2}{*}{ S. No. } & \multirow[t]{2}{*}{ Isolates } & \multicolumn{3}{|c|}{ Colony characteristics } \\
\hline & & Color & Shape & Size $(\mathbf{m m})$ \\
\hline $\mathbf{A}$ & Cmm1 & Yellow & Round, mucoid & $1-2$ \\
\hline $\bar{B}$ & $\mathrm{Cmm2}$ & Cremish yellow & Round & $1-3$ \\
\hline $\bar{C}$ & $\mathrm{Cmm3}$ & Yellow & Circular, fluidal & $1-3$ \\
\hline $\mathbf{D}$ & $\mathrm{Cmm} 4$ & Yellow & Circular & $2-4$ \\
\hline $\mathbf{E}$ & $\mathrm{Cmm5}$ & Yellow & Round, mucoid & $2-3$ \\
\hline $\bar{F}$ & Cmm6 & Orange & Round & $1-3$ \\
\hline $\mathbf{G}$ & $\mathrm{Cmm} 7$ & Orange & Round & $1-3$ \\
\hline $\mathbf{H}$ & $\mathrm{Cmm8}$ & Orange & Circular, fluidal & $2-4$ \\
\hline $\mathbf{I}$ & Cmm9 & Orange & Circular & $2-3$ \\
\hline$\overline{\mathrm{J}}$ & $\mathrm{Cmm} 10$ & Orange & Round, mucoid & $1-3$ \\
\hline
\end{tabular}




\section{Evaluation of the colony characteristics of} the $\mathrm{Cmm}$ isolates

To distinguish the cultural variability in different $\mathrm{Cmm}$ isolates $(\mathrm{Cmm} 1, \mathrm{Cmm} 2, \mathrm{Cmm} 3$, Cmm4, Cmm5, Cmm6. Cmm7, Cmm8, Cmm9 and $\mathrm{Cmm} 10$ ), the isolates were grown on single nutrient agar glucose yeast (NGY) medium. The colony characteristics of these isolates were recorded and presented in Table 2 (Plate 3 ).

On NGY medium, the bacterial colonies of the different isolates were small, ranging betwwn 1$4 \mathrm{~mm}$ in diameter and could be observed within $72-96 \mathrm{~h}$ of incubation at $28^{\circ} \pm 1^{\circ} \mathrm{C}$. The bacterial colonies in all the isolates started as round, semi fluidal, glistening and concave to dome shaped (Plate- 5). The colony color of the bacterial isolates varied and $C m m$ 1, 3, 4 and 5 exhibited yellow colonies whereas isolate $\mathrm{Cmm} 2$, the colonies were creamish white to yellow. The bacterial colonies were observed orange in color in isolates $\mathrm{Cmm} \mathrm{6,} \mathrm{7,} \mathrm{8,} 9$ and 10 (Table 2). In EPPO Bulletin, (2013) both yellow and orange colonies of $\mathrm{Cmm}$ have been reported and mentioned nonselective and semi-selective media as important diagnostic tools for identification of $\mathrm{Cmm}$.

\section{Biofilm like structure formation by $\mathrm{Cmm}$ on different media}

In vitro assay, for biofilm like structure formation was studied for four most virulent strains of $\mathrm{Cmm}$ (1, 5, 6 and 10). The most preferable medium for biofilm aggregation for all the $\mathrm{Cmm}$ isolates was xylem sap. Amongst these isolates the maximum aggregation of bacterial cells was in isolate $\mathrm{Cmm} 5$ which could be confirmed by spectrophotometric determination (OD590) of the adherent cells assayed by crystal violet staining indicated the OD value of $\mathrm{Cmm} 5$ isolate in different media and it was 0.546 in XS as compared with 0.207, 0.198, and 0.109 in M9, LB and DW, respectively. Isolate $\mathrm{Cmm} \mathrm{1;} \mathrm{irrespective} \mathrm{of}$ growing in any of the medium, the least aggregation of bacterial cells was observed (Plate4) (Fig. 3).
The biofilm like structure are formed by the bacterial adherence on the substrate or in the medium preferred by the bacterium for its growth as well as the nature of the bacterium can also be inferred. The results are in the confirmation of the findings of Chalopowicz et al., 2011, wherein the maximum biofilm formation was observed in the xylem sap of the tomato plant and least in the minimal medium.

C. michiganensis subsp. michiganensis is one of the most dangerous bacterium infecting tomato crop, and despite the continuous management efforts, disease incidence outbreaks occur frequently. For the purpose of detection, plating on semiselective medium still remains one of the convenient and reliable methods for the detection of bacterium. $\mathrm{D}_{2}$ ANX medium was observed to be the effective medium for the isolation of the bacterium from the infected plants. The highest biofilm like structure formation in the xylem sap by the all the four isolates of the bacterium suggest its vascular preference, thereby proving the bacterium as systemic in nature.

\section{References}

Chalupowicz L, Dror O, Cohen-Kandli M, Eichenlaub R, Zellermann E, Gartemann K, Sessa G, Barash I, S Manulis-Sasson. 2010. $\mathrm{Cmm}$-tomato interactions: Visualization during infection, biofilm formation and epiphytic fitness. Phytopathology 100: S22

Chang RJ, Ries SM, Pataky JK. 1991. Dissemination of Clavibacter michiganensis subsp. michiganensis by practices used to produce tomato transplants. Phytopathology 81: 1276-1281.

Chun WCC. 1982. Identification and detection of Corynebacterium michiganense in tomato seed using the indirect enzyme-linked immunosorbent assay. MSc Thesis. Honolulu, HI, USA: University of Hawaii.

Danhorn T, Fuqua C.2007 Biofilm formation by plant-associated bacteria. Annual Review of Microbiology 61:401-422.

Davey, M. E. and O'Toole, G. A. (2000). Microbial biofilms: from ecology to 
molecular genetics. Microbiology and Molecular Biology Review 64: 847-867.

EPPO bulletin. 2016. PM 7/42 (3) Clavibacter michiganensis subsp. michiganensis. OEPP/EPPO Bulletin. 46: 202-225.

EPPO/CABI. 2005. Clavibacter michiganensis subsp. michiganensis. EPPO Bulletin.

Fatmi M, Schaad NW. 1988. Semiselective agar medium for isolation of Clavibacter michiganensis ssp. michiganensis from tomato seed. Phytopathology 78: 121-126.

Fatmi, M.; and Schaad, N.W. 1988. Semiselective agar medium for isolation of Clavibacter michiganense subsp michiganense from tomato seed. Phytopathology 78: 121-126. Ftayeh R, Mavridis A und Rudolph K, 2004. Überleben des Erregers der bakteriellen Insel Reichenau. Magisterarbeit, Universität Göttingen.

Ftayeh R, 2004. Vorkommen, Epidemiologie und Bekämpfungsmöglichkeiten der bakteriellen Tomatenwelke (Clavibacter michiganensis ssp. michiganensis) auf der Insel Reichenau. Magisterarbeit, Universität Göttingen.

Ftayeh R, Mavridis A and Rudolph K. 2004. Überleben des Erregers der bakteriellen Tomatenwelke, Clavibacter michiganensis ssp. michiganensis, im Boden bei unterschiedlichen Bedingungen. Mitteilungen der Biologischen Bundesanstalt für Land- und Forstwirtschaft 396, 348

Ftayeh, R.M, von Tiedemann A, Rudolph KWE. 2011. A New Selective Medium for Isolation of Clavibacter michiganensis subsp michiganensis from Tomato Plants and Seed. Phytopathology 101(11):135564.
Gitaitis RD, Sumner D, Gay D, Smittle D, MacDonald G, Maw B, Johnson WC III, Tollner B, Hung Y, 1997. Bacterial streak and bulb rot of onion: I. A diagnostic medium for the semiselective isolation and enumeration of Pseudomonas viridiflava. Plant Disease 81:897-900.

Hadas R, Kritzman G, Klietman F, Gefen T and Manulis S, 2005. Comparison of extraction procedures and determination of the detection threshold for Clavibacter michiganensis ssp. michiganensis in tomato seeds. Plant Pathology 54: 643-649.

Janse JD. 2004. Management of bacterial diseases of plants: Regulatory aspects. in: Encyclopedia of Plant and Crop Science. R. M.Goodman, ed. Marcel Dekker, Pp. 669674Inc., New York.

Roy MA, Sasser M. 1990. Selective media: principles of design and use. In: Methods in Phytobacteriology (Klement Z, Rudolph K and Sands DC eds.). Pp. 62-65, Akademiai Kiado, Budapest.

Schaad NW. 1982. Detection of seedborne bacterial plant pathogens. Plant Disease 66: 885-890.

Strider DL. 1969. Bacterial canker of tomato caused by Corynebacterium michiganense: A literature review and bibliography. N.C. Agric. Exp. Stn. Tech. Bull. No. 193.

Umesha S. 2006. Occurrence of bacterial canker in tomato fields of Karnataka and effect of biological seed treatment on disease incidence. Crop Protection 25: 375-381.

Werner NA, Fulbright DW, Podolsky R, Bell J, Hausbeck MK, 2002. Limiting population and spread of Clavibacter michiganensis subsp. michiganensis on seedling tomatoes in the greenhouse. Plant Disease 86: 535-42.

\section{How to cite this article:}

Ruchi Tripathi, Rashmi Tiwari and Vishunavat, K. 2018. Evaluation of Different Growth Media for Clavibacter michiganensis subsp michiganensis and Formation of Biofilm like Structures. Int.J.Curr.Microbiol.App.Sci. 7(05): 207-216. doi: https://doi.org/10.20546/ijcmas.2018.705.027 